International Research Journal of Management, IT \& Social Sciences
Available online at https://sloap.org/journals/index.php/irjmis/
Vol. 6 No. 2, March 2019, pages: 52 62
ISSN: 2395-7492
https://doi.org/10.21744/irjmis.v6n2.608

\title{
Role of Transformational Leadership Mediation: Effect of Emotional and Communication Intelligence towards Teamwork Effectiveness
}

I Gusti Made Suwandana ${ }^{a}$

Article history:

Received: 27 September 2018

Accepted: 31 January 2019

Published: 23 March 2019

\section{Keywords:}

emotional;

intelligence;

teamwork effectiveness;

communication;

transformational leadership;

\begin{abstract}
Tourism has become a driving factor for the economy in various countries in the world. Regions that become tourist destinations have a great chance of growing supporting facilities such as the provision of accommodation, restaurants and transportation services. Bali has long been an attraction for both local and foreign tourists to visit. A large number of tourists visiting Bali has added opportunities for the tourism industry in providing accommodation services and facilities for tourists. This research was conducted to find out that transformational leadership mediates on the influence of emotional intelligence and communication on the effectiveness of the teamwork. The results show that emotional intelligence has a positive and significant effect on transformational leadership. Communication has a positive and significant effect on transformational leadership. Emotional intelligence has a positive and significant effect on team effectiveness. Communication has a positive and significant effect on team effectiveness. Transformational leadership has a positive and significant effect on team effectiveness. Transformational leadership is able to mediate the influence of emotional intelligence on team effectiveness. Transformational. Transformational leadership is able to mediate the influence of communication on team effectiveness.
\end{abstract}

2395-7492@ Copyright 2019. The Author. This is an open-access article under the CC BY-SA license (https://creativecommons.org/licenses/by-sa/4.0/) All rights reserved.

\section{Author correspondence:}

Suwandana,

Faculty Economic and Business, Udayana University, Denpasar, Indonesia

Jalan P.B. Sudirman, Denpasar; Email: info@unud.ac.id; Tlp/Fax: +62 (361) 223797 / +62 (361) 701907

Email address: gungdesuwandana@unud.ac.id

${ }^{\mathrm{a}}$ Faculty Economic and Business, Udayana University, Denpasar, Indonesia 


\section{Introduction}

Team effectiveness is a team effort to achieve agreed goals so that it can affect the company, its team members, and the sustainability of the team (Estianda, 2014). Increasing the effectiveness of the team will bring progress for the company to be able to survive in a competitive business environment that is not stable. Efforts to improve the effectiveness of the teamwork are the most serious management challenges because the success of achieving the goals and survival of the company depends on the quality of the work of human resources in it. Decreasing team effectiveness in work can be improved by increasing the emotional intelligence of members of organizations or companies.

Emotional intelligence is the ability to feel, understand and effectively apply emotional sensitivity as a source of energy, information, connection, and human influence (Goleman, 2015). Emotional intelligence can create a dynamic teamwork atmosphere because all employees can control all egos, desires, and understand other employees (Tantriana, 2015). Emotional intelligence requires good communication with each other within the organization to improve team effectiveness at work.

Organizational communication is communication that takes place in an organizational environment including sending and receiving messages between two or more people, between groups of people, or in one or several fields that influence organizational behavior. Femi (2014), states that effective communication between superiors and subordinates is very important for the success of the company. Kiswanto (2010), states that communication has a significant effect on employee performance. Ardana et al., (2012: 138), states that with communication someone can convey his wishes buried in his heart to others, whether through voice or motion, gestures of the body and so on. Rosita (2013), states that communication has a very important role in achieving effective leadership. Communication networks that take place show that the message flow that occurs is not only limited to formal communication networks, but also informal communication.

High emotional intelligence and organizational communication possessed by company employees will be influenced by transparent leadership styles, namely transformational leadership. Transformational leadership ensures mutually beneficial social relations with subordinates (Yulk, 2006). Transformational leaders change and motivate employees to improve their performance. Azzahra (2013), shows that emotional intelligence has a positive and significant effect on transformational leadership.

Transformational leaders are needed by every employee, with transformational leadership will make the emotional intelligence of each individual can be controlled properly, so as to increase the effectiveness of the team in the company. Azzahra (2013), has shown that transformational leadership has a positive effect on team effectiveness. But it is different from research Y. Hur et al., (2011), the results show that transformational leadership does not have a positive effect on the effectiveness of the teamwork. Azzahra (2013), states that emotional intelligence has a positive effect on team effectiveness and mediated by transformational leadership.

Leaders who have high emotional intelligence can be said to be able to create effective teamwork, because transformational leadership is able to lead a team by creating conditions and a team environment that is conducive and comfortable for its team members.

Developments in tourism accommodation such as hotels and restaurants in Bali have an impact on increasingly competitive competition. This situation requires hotel and restaurant leaders and employees to always work professionally in providing the best service. Increasingly tight competition, especially the hospitality business, requires hotel management to always provide more complete facilities and services that are more satisfying for tourists. Hotel management must motivate their employees to do their best and encourage employees to fulfill their responsibilities as employees.

\section{Literature Review}

The results of Mula (2013), study state that emotional intelligence has a positive effect on transformational leadership behavior. From the results of research Y. Hur et al., (2011), stated that factors in transformational leadership have a positive correlation with emotional intelligence. The results of Shahram Alam (2014), showed a positive correlation between emotional intelligence and transformational leadership style. From the results of the research by Nooshin Esfahani et al., (2011), show that there is a positive and significant influence between emotional intelligence and formal leadership. The same results were also obtained by Putra (2012), that emotional intelligence has a significant effect on transformational leadership. Nida Azzahra (2013), shows that emotional intelligence has a positive relationship with transformational leadership. Based on empirical results in the above research, the hypothesis that can be proposed in this study are:

Suwandana, I. G. M. (2019). Role of transformational leadership mediation: effect of emotional and communication intelligence towards teamwork effectiveness. International Research Journal of Management, IT and Social Sciences, 6(2), 52-62. https://doi.org/10.21744/irjmis.v6n2.608 
H1: Emotional intelligence has a positive and significant effect on transformational leadership.

Rosita (2013), states that communication has a very important role in achieving effective leadership. Communication networks that take place show that the message flow that occurs is not only limited to formal communication networks, but also informal communication. Linda (2011), stated that the role of communication in leadership is one of the most important factors in the process and interaction of government and development activities as an effort to strengthen and provide understanding to the community about the programs that will be implemented to improve community welfare. Based on empirical results in the above research, the hypothesis that can be proposed in this study are:

$\mathrm{H} 2$ : Communication has a positive and significant effect on transformational leadership.

Fikrie Anugrah (2017), in her research, found that emotional intelligence has a positive and significant effect on the effectiveness of employee team works. Kusnara (2013), in his study, showed that emotional intelligence has a positive and significant effect on the effectiveness of the teamwork. Evo Hariandja (2007), in his research also showed that emotional intelligence has a positive effect on the effectiveness of teams in an organization. Saqib Khan et al., (2014), in his research, stated that there is a positive effect of emotional intelligence on team effectiveness. The results of research by Harminder, K, G \& Jaya, A. (2011), show a positive impact of emotional intelligence on the effectiveness of the teamwork. Based on empirical results in the above research, the hypothesis that can be proposed in this study are:

H3: Emotional intelligence has a positive and significant effect on team effectiveness.

The results of Fauziah (2012), study show that communication can improve the effectiveness of team works, where communication has a positive and significant effect on team effectiveness. Muhsin (2005), concluded that internal communication has a positive effect on teacher work effectiveness. Then, Pebri (2013), states that communication within organizations plays a role in increasing the effectiveness of team works where communication has a positive and significant effect on team effectiveness. Nevi (2016), states that leadership communication has a large influence on the work efficiency of employees in the Pratama Jambi tax service office and the magnitude of the influence in the category of strong influence. Reza (2014), concluded that organizational communication has a positive and significant effect on work effectiveness. Based on empirical results in the above research, the hypothesis that can be proposed in this study are:

H4: Communication has a positive and significant effect on team effectiveness.

The results of Lopez (2015), show that the use of transformational leadership can increase the effectiveness of team work. Tabassi (2013), states that transformational leadership has a significant impact on team effectiveness. Wahba (2016), the results of his research showed that there was a significant positive impact on the effect of transformational leadership on the effectiveness of the teamwork. Y. Hur et al., (2011), stated that transformational leadership has a positive effect on team effectiveness. Azzahra (2013), shows that transformational leadership has a positive relationship with team effectiveness. Based on empirical results in the above research, the hypothesis that can be proposed in this study is.

H5: Transformational leadership has a positive and significant effect on team effectiveness.

Azzahra (2013), states that transformational leadership is the mediator of the relationship between emotional intelligence to team effectiveness. Lam \& Higgins (2015), stated that transformational leadership styles fully mediate the relationship between emotional intelligence and the effectiveness of a team. Vierimaa (2013), states that emotionally intelligent leaders can increase the effectiveness of team works through transformational leadership that identifies and understands team members' emotions and acts according to what is best for companies and individuals as team members. The results of the study by Schlechter (2008), stated that transformational leadership mediates the relationship between emotional intelligence and effectiveness in team performance. Based on empirical results in the above research, the hypothesis that can be proposed in this study is.

H6: Transformational leadership is able to mediate the influence of emotional intelligence on team effectiveness. Surbakti (2013), explained that the interaction between leaders who have a transformational leadership style and subordinates is characterized by the size of the influence given by the leader to his subordinates to change. Leaders applying this type of transformational leadership will tend to spur followers to produce jobs beyond what is expected, namely by changing their vision, giving examples, giving support, and stimulating the desire to change towards a better direction. Ita (2014), concluded that the influence between transformational leadership style variables on 
organizational effectiveness has an indirect relationship through decision making. Prati et al., (2003), the results of his research state that team leaders who are emotionally intelligent use transformational influences to improve effective team performance. Based on empirical results in the above research, the hypothesis that can be proposed in this study are:

H7: Transformational leadership is able to mediate the influence of communication on team effectiveness.

\section{Materials and Methods}

The research location is located at Pertiwi Group, located in Ubud, Bali. This location was chosen because it has three hotels and restaurants in Bali, namely Pertiwi Suites, Pertiwi Bisma Resort, and Pertiwi Resort and Spa. other than that because there are problems with the effectiveness of the team within the company and there is still little research that examines in the field of tourism accommodation, especially hotels and restaurants. The population of this study was all employees in the Pertiwi Group, which numbered 159 people. The method used in this study uses a saturated sample, where the entire study population was chosen as a sample of 159 employees outside the company leader or the director of the Pertiwi Group in accordance with the organizational structure. The data analysis technique used in this study is Path Analysis, which is an extension of multiple linear regression analysis in estimating causality between previously predetermined variables based on theory.

\section{Results and Discussions}

Calculation of path coefficients is done by regression analysis through SPSS 24.0 for Windows software, the results obtained are shown in the following Table 1.

Table 1

Path I

\begin{tabular}{|c|c|c|c|c|c|}
\hline \multirow[t]{2}{*}{ Variable } & \multicolumn{2}{|c|}{ Unstandardized Coefficients } & \multirow{2}{*}{$\begin{array}{c}\text { Standardized Coefficients } \\
\text { Beta }\end{array}$} & \multirow{2}{*}{ t-account } & \multirow{2}{*}{ Sig. t-test } \\
\hline & $\mathrm{B}$ & Std. Error & & & \\
\hline (Constant) & 6.952 & .988 & & 7.038 & .000 \\
\hline Emotional Intelligence $\left(\mathrm{X}_{1}\right)$ & .187 & .051 & .272 & 3.661 & .000 \\
\hline Communication $\left(\mathrm{X}_{2}\right)$ & .335 & .060 & .416 & 5.598 & .000 \\
\hline R Square & 0,363 & & & & \\
\hline F Statistics & 44,531 & & & & \\
\hline Significance of F-test & 0,000 & & & & \\
\hline
\end{tabular}

Primary Data, 2019

Based on the results of model 1 path analysis as presented in Table 1, the structural equation can be made as follows.

$M_{=} \beta_{1} X_{1}+\beta_{2} X_{2}+e_{1}$

$M_{=} 0,272 X_{1}+0,416 X_{2}+0,060$

Regression coefficient value of Emotional Intelligence and Communication variables is positive with a significance value of t-test less than 0.05. This shows that the variable Emotional Intelligence and Communication has a significant positive influence on the variable Transformational Leadership. The magnitude of the influence of independent variables on the dependent variable indicated by the value of total determination ( $\mathrm{R}$ Square) of 0.355 means that $36.3 \%$ of the variation in Transformational Leadership is influenced by variations in Emotional Intelligence and Communication, while the remaining $63.7 \%$ is explained by other factors not included in the model.

Suwandana, I. G. M. (2019). Role of transformational leadership mediation: effect of emotional and communication intelligence towards teamwork effectiveness. International Research Journal of Management, IT and Social Sciences, 6(2), 52-62. https://doi.org/10.21744/irjmis.v6n2.608 
Table 2

Path II

\begin{tabular}{llllll}
\hline \multirow{2}{*}{ Variable } & \multicolumn{2}{l}{$\begin{array}{l}\text { Unstandardized } \\
\text { Coefficients }\end{array}$} & $\begin{array}{l}\text { Standardized } \\
\text { Coefficients } \\
\text { Beta }\end{array}$ & t-account & Sig. t-test \\
& $\mathrm{B}$ & Std. Error & . & & \\
\hline (Constant) & 2.688 & .617 & & 4.354 & .000 \\
Emotional Intelligence $\left(\mathrm{X}_{1}\right)$ & .160 & .029 & .334 & 5.522 & .000 \\
Communication $\left(\mathrm{X}_{2}\right)$ & .180 & .036 & .321 & 5.047 & .000 \\
Transformational Leadership $\left(\mathrm{Y}_{1}\right)$ & .207 & .044 & .297 & 4.754 & .000 \\
R Square & 0,615 & & & & \\
F Statistics & 82,449 & & & & \\
Significance of F-test & 0,000 & & & & \\
\hline
\end{tabular}

Primary Data, 2019

Based on the results of model 2 path analysis as presented in Table 2, the structural equation can be made as follows.

$\mathrm{Y}=\beta_{3} \mathrm{X}_{1}+\beta_{4} \mathrm{X}_{2}+\beta_{5} \mathrm{Y}_{1}+\mathrm{e}_{2}$

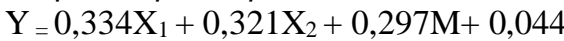

Regression coefficient value of Emotional Intelligence, Communication and Transformational Leadership variables is positive with a significance value of t-test less than 0.05. This shows that the variables of Emotional Intelligence, Communication, and Transformational Leadership have a significant positive effect on the Green Repurchase Intention variable. The magnitude of the influence of independent variables on the dependent variable indicated by the value of total determination (R Square) of 0.615 means that $61.5 \%$ of the variation of Green Repurchase Intention is influenced by variations in Emotional Intelligence, Communication, and Transformational Leadership, while the remaining 38.5\% is explained by other factors not included in the model.

Based on model 1 and substructure 2, then the final path diagram model can be arranged. Before compiling the final path diagram model, the error standard value is calculated first:

$\mathrm{Pe}_{\mathrm{i}}=\sqrt{1-\mathrm{R}_{\mathrm{i}}^{2}}$

$\mathrm{Pe}_{1}=\sqrt{1-R_{1}^{2}}=\sqrt{1-0,363}=0,798$

$\mathrm{Pe}_{2}=\sqrt{1-R_{2}^{2}}=\sqrt{1-0,615}=0,620$

Based on the calculation of the effect of error (Pei), the result of the effect of error (Pe1) is 0.798 and the effect of error $(\mathrm{Pe} 2)$ is 0.620 . The results of the total coefficient of determination are as follows.

$$
\begin{aligned}
& \mathrm{R}^{2}{ }_{\mathrm{m}}=1-\left(\mathrm{Pe}_{1}\right)^{2}\left(\mathrm{Pe}_{2}\right)^{2} \\
& =1-(0,798)^{2}(0,620)^{2} \\
& \quad=1-(0,638)(0,384) \\
& \quad=1-0,245=0,754
\end{aligned}
$$

The total determination value of 0.754 means that as much as $75.4 \%$ variation Team effectiveness is influenced by variations in Emotional Intelligence, Communication, and Transformational Leadership, while the remaining $24.6 \%$ is explained by other factors not included in the model. The calculation of the influence between variables is summarized in Table 3 as follows. 
Table 3

Indirect Effect

\begin{tabular}{llll}
\hline Variable & Direct Effect & Indirect Effect & Total Effect \\
\hline $\mathrm{X}_{1} \rightarrow \mathrm{M}$ & 0,272 & - & 0,272 \\
$\mathrm{X}_{1} \rightarrow \mathrm{Y}$ & 0,334 & 0,081 & 0,415 \\
$\mathrm{M} \rightarrow \mathrm{Y}$ & 0,297 & - & 0,297 \\
\hline
\end{tabular}

Primary Data, 2019

Table 3 shows that the direct effect of Emotional Intelligence on Transformational Leadership is 0.272. The direct effect of the Emotional Intelligence variable on Team Effectiveness is 0.334. The direct effect of the Transformational Leadership variable on Team Effectiveness is 0.297. This means that the Team Effectiveness variable is more influenced by Emotional Intelligence than Transformational Leadership. While the indirect effect of Emotional Intelligence variable on Team Effectiveness through Transformational Leadership is 0.081. So the total effect of the Emotional Intelligence variable on Team Effectiveness through Transformational Leadership is 0.415 . So it can be concluded that the greater the total effect of Emotional Intelligence on Team Effectiveness through Transformational Leadership, rather than the direct influence of Emotional Intelligence on Team Effectiveness without going through the variables of Transformational Leadership.

Table 4

Indirect Effect

\begin{tabular}{llll}
\hline Variable & Direct Effect & Indirect Effect & Total Effect \\
\hline $\mathrm{X}_{2} \rightarrow \mathrm{M}$ & 0,416 & - & 0,416 \\
$\mathrm{X}_{2} \rightarrow \mathrm{Y}$ & 0,321 & 0,123 & 0,444 \\
$\mathrm{M} \rightarrow \mathrm{Y}$ & 0,297 & - & 0,297 \\
\hline
\end{tabular}

Primary data, 2019

Table 4 shows that the direct effect of Communication on Transformational Leadership is 0.416 . The direct effect of the Communication variable on Team Effectiveness is 0.321 . The direct effect of the Transformational Leadership variable on Team Effectiveness is 0.297. This means that the Team Effectiveness variable is more influenced by Communication than Transformational Leadership. While the indirect effect of the Communication variable on Team Effectiveness through Transformational Leadership is 0.123 . So the effect of the total Communication variable on Team Effectiveness through Transformational Leadership is 0.444 . So it can be concluded that the greater the total effect of Communication on Team Effectiveness through Transformational Leadership, rather than the direct effect of Communication on Team Effectiveness without going through the variables of Transformational Leadership.

The Sobel Test was conducted to test the significance of the indirect influence of Emotional Intelligence (X1) and Communication (X2) variables on Team Effectiveness (Y) through Transformational Leadership variable (M) by multiplying the path coefficient X to $\mathrm{M}$ (a) with the path coefficient $\mathrm{M}$ to $\mathrm{Y}$ (b) or ab. Standard error coefficients a and $\mathrm{b}$ are written with $\mathrm{Sa}$ and $\mathrm{Sb}$, the magnitude of the indirect standard error (indirect effect) is written with Sat. To test the significance of the indirect effect, the calculated $t$ value of the ab coefficient is calculated as follows:

$$
\begin{aligned}
& S_{a b}=\sqrt{(0,297)^{2}(0,060)^{2}+(0,272)^{2}(0,040)^{2}+(0,060)^{2}(0,040)^{2}} \\
& S_{a b}=0,005
\end{aligned}
$$

To test the significance of the indirect effect, calculate the calculated t value from the coefficient ab with the following formula:

$$
\begin{gathered}
\text { t value }=\frac{a b}{S a b} \\
t \text { value }=\frac{(0,272)(0,297)}{0,005} \\
t \text { value }=\frac{(0,081)}{0,005}
\end{gathered}
$$

Suwandana, I. G. M. (2019). Role of transformational leadership mediation: effect of emotional and communication intelligence towards teamwork effectiveness. International Research Journal of Management, IT and Social Sciences, 6(2), 52-62. https://doi.org/10.21744/irjmis.v6n2.608 
t value $=16,157$

Therefore $t$ value is $16.157>1.96$. This means that transformational leadership is able to mediate the influence of emotional intelligence on team effectiveness.

To test the significance of the indirect effect, the calculated $t$ value of the ab coefficient is calculated as follows:

$$
\begin{aligned}
& S_{a b}=\sqrt{(0,297)^{2}(0,060)^{2}+(0,416)^{2}(0,040)^{2}+(0,060)^{2}(0,040)^{2}} \\
& S_{a b}=0,006
\end{aligned}
$$

To test the significance of the indirect effect, calculate the calculated t value from the coefficient ab with the following formula:

$$
\begin{aligned}
t \text { value } & =\frac{a b}{S a b} \\
t \text { value } & =\frac{(0,416)(0,297)}{0,006} \\
t \text { value } & =\frac{(0,123)}{0,006} \\
t \text { value } & =20,592
\end{aligned}
$$

Therefore $t$ value is $20.592>1.96$. This means that transformational leadership is able to mediate the influence of communication on team effectiveness.

VAF is a measure of how much the mediating variable is able to absorb the previously significant direct influence of the model without mediation. For the model, VAF can be calculated with $(\mathrm{b} x \mathrm{c}) /(\mathrm{a}+\mathrm{b} \times \mathrm{c})$. If the VAF value is above 80 percent, then it shows the role of Y1 as full mediation. Furthermore, if the VAF value is between 20 percent and 80 percent, it can be categorized as partial mediation. However, if the VAF value is less than 20 percent, it can be explained that there is almost no mediating effect.

$$
\begin{aligned}
\mathrm{VAF} & =(0,297 \times 0,334) /(0,272+0,297 \times 0,334) \\
& =0,100 / 0,371 \\
& =0,269(26,9 \%)
\end{aligned}
$$

Because the value of VAF (26.9 percent) is more than 20 percent, it can be explained that there is a mediating effect or in other words Transformational Leadership as partial mediation.

$$
\begin{aligned}
\text { VAF }=(0,297 & \times 0,321) /(0,416+0,297 \times 0,321) \\
& =0,096 / 0,411 \\
& =0,233(23,3 \%)
\end{aligned}
$$

Because the value of $\operatorname{VAF}$ (23.3 percent) is more than 20 percent, it can be explained that there is a mediating effect or in other words Transformational Leadership as partial mediation.

\section{Conclusion}

Emotional intelligence has a positive and significant effect on transformational leadership. This shows that if Emotional Intelligence increases it will also increase transformational leadership. Communication has a positive and significant effect on transformational leadership. This shows that if communication increases it will also increase transformational leadership. Emotional intelligence has a positive and significant effect on team effectiveness. This shows that if Emotional Intelligence increases it will also increase team effectiveness.

Communication has a positive and significant effect on team effectiveness. This shows that if communication increases it will increase the effectiveness of the team. Transformational leadership has a positive and significant effect on team effectiveness. This shows that if transformational leadership increases it will also increase team effectiveness. Transformational leadership is able to mediate the influence of emotional intelligence on team effectiveness. This 
shows that emotional intelligence has a significant impact on team effectiveness if mediated by transformational leadership, which means that the influence of emotional intelligence on team effectiveness will be strengthened by the existence of transformational leadership.

Transformational leadership is able to mediate the influence of communication on team effectiveness. This shows that communication has a significant impact on team effectiveness if mediated by transformational leadership, which means that the influence of communication on team effectiveness will be strengthened by the existence of transformational leadership.

Conflict of interest statement and funding sources

The author declared that he has no competing interest. The study was financed by personal funding.

Statement of authorship

The author has a responsibility for the conception and design of the study. The author has approved the final article.

Acknowledgments

The author would like to thank the editor of IRJMIS for their support, valuable time, and advice.

Suwandana, I. G. M. (2019). Role of transformational leadership mediation: effect of emotional and communication intelligence towards teamwork effectiveness. International Research Journal of Management, IT and Social Sciences, 6(2), 52-62. https://doi.org/10.21744/irjmis.v6n2.608 


\section{References}

Ardana, K. Ni Wayan Mujiati dan Anak Agung Ayu Sriathi, 2012, Perilaku Keorganisasian.

Ariessetyawati, N. (2016). Pengaruh Komunikasi Kepemimpinan terhadap Efektivitas Kerja Pegawai di Kantor Pelayanan Pajak Pratama Jambi. Jurnal Online Mahasiswa (JOM) Bidang Ilmu Sosial dan Ilmu Politik, 3(1), 1-15. https://jom.unri.ac.id/index.php/JOMFSIP/article/view/9320/8985

Azzahra, N. M., Adiwijaya, A., \& Triantoro, D. (2015). Algoritma Discrete Cosine Transform (dct) Dan Absolute Moment Block Truncation Coding (ambtc) Pada Sistem Watermarking Untuk Deteksi Dan Recovery Citra Medis $\begin{array}{llll}\text { Termodifikasi. eProceedings } & \text { of } & \text { Engineering, } & 2(2) \text {. }\end{array}$ https://libraryeproceeding.telkomuniversity.ac.id/index.php/engineering/article/view/3028/2873

Batool, B. F. (2013). Emotional intelligence and effective leadership. Journal of Business Studies Quarterly, 4(3), 84. http://novintarjome.com/wp-content/uploads/2013/10/March_2013_8.pdf

Esfahani, N., \& Soflu, H. G. (2011). Relationship between emotional intelligence and transformational leadership in physical education managers. Procedia-Social and Behavioral Sciences, 30, 2384-2393. https://doi.org/10.1016/j.sbspro.2011.10.465

Estianda, Y. (2014). Pengaruh Kepribadian Dan Efektivitas Tim Terhadap Organizational Citizenship Behavior (Ocb) Pegawai Di Badan Pendidikan Dan Pelatihan Kementerian Dalam Negeri. Jurnal Manajemen Pendidikan, 5(2). http://journal.unj.ac.id/unj/index.php/jmp/article/view/1972

Femi, A. F. (2014). The impact of communication on workers' performance in selected organisations in Lagos State, Nigeria. IOSR Journal Of Humanities And Social Science (IOSR-JHSS), 19(8), 75-82. https://www.researchgate.net/profile/Asamu_Femi/

Fikrie, M. A., Sasmita, J., \& Rifqi, A. (2016). Pengaruh Kemampuan, Sikap Dan Kecerdasan Emosional Terhadap Efektivitas Kerja Pegawai Dinas Pariwisata Dan Ekonomi Kreatif Provinsi Riau. Jurnal Online Mahasiswa (JOM) Bidang Ilmu Ekonomi, 4(1), 694-708. https://jom.unri.ac.id/index.php/jomfekon/article/viewFile/12949/12591

Fitriyani, D., Prasetyo, E., Mirdah, A., \& Putra, W. E. (2012). Pengaruh Manajemen Laba terhadap Kinerja Perusahaan dengan Kualitas Audit sebagai Variabel pemoderasi. Jurnal. http://www.sna.akuntansi.unikal.ac.id/makalah/033AKPM-52.pdf

Ghaloojeei, R., Nikbakhsh, R., \& Alam, S. (2014). The relationship between information and communications technology (ICT) and organizational learning in Department of Youth and Sports of Alborz Province. European Online Journal of Natural and Social Sciences: Proceedings, 2(3 (s)), pp-1696. http://europeanscience.com/eojnss_proc/article/view/3867

Goleman, D., \& Jankowski, A. (2015). Inteligencja społeczna. Dom Wydawniczy Rebis.

Gujral, H. K., \& Ahuja, J. A. Y. A. (2011). Impact of emotional intelligence on teamwork: A comparative study of self-managed and cross functional teams. Zenith International Journal of Multidisciplinary Research, 1(6), 178185. https://www.researchgate.net/profile/Harminder_Gujral/

Hariandja, E. S., \& Kautsar, A. W. (2007). Strategi Perusahaan dalam Pengembangan Produk Baru: Penelitian Kasus Perusahaan Manufaktur di Indonesia. INASEA, 8(1), 58-68. http://researchdashboard.binus.ac.id/uploads/paper/document/publication/Journal/Inasea/Vol\%208\%20No\%201\%20April\%202 007/05_Evo\%20S.\%20Hariandja_Manufaktur.pdf

Hur, Y., van den Berg, P. T., \& Wilderom, C. P. (2011). Transformational leadership as a mediator between emotional intelligence and team outcomes. The Leadership Quarterly, 22(4), 591-603. https://doi.org/10.1016/j.leaqua.2011.05.002

Khan, S., Khan, I., Akhtar, B., Khan, F., Yar, N., Khan, N., ... \& Rauf, H. (2014). The Impact of Emotional Intelligence upon the Team Effectiveness. Research on Humanities and Social Sciences, 4(22), 1-7. https://www.researchgate.net/profile/Muhammad_Saqib_Khan/

Kiswanto, M. (2010). Pengaruh Kepemimpinan dan Komunikasi Terhadap Kinerja Karyawan Kaltim Pos Samarinda. Jurnal Eksis, 6(1), 1429-1439. http://karyailmiah.polnes.ac.id/

Kusnara, K. (2013). Pengaruh komunikasi interpersonal dan kecerdasan emosional terhadap efektivitas kerja guru di uptd pendidikan kecamatan cibingbin kabupaten kuningan. Administrasi Pendidikan: Jurnal Ilmiah Mahasiswa Pascasarjana, 1(1), 99-106.

Linda Christine. (2011). Peranan komunikasi dalam kepemimpinan pemerintahan dan partisipasi masyarakat. Jurnal Universitas Kristen Indonesia.

Lizawati, I. (2015). Pengaruh gaya kepemimpinan transformasional terhadap efektivitas organisasi melalui $\begin{array}{llllll}\text { pengambilan } & \text { keputusan. Jurnal }\end{array}$ https://jurnalmahasiswa.unesa.ac.id/index.php/jim/article/download/11156/10654 
Lopez, M. (2015). Analyzing the Relationship Between Transformational Leadership Behavior and Team. ProQuest Number: 3720731

Melita Prati, L., Douglas, C., Ferris, G. R., Ammeter, A. P., \& Buckley, M. R. (2003). Emotional intelligence, leadership effectiveness, and team outcomes. The International Journal of Organizational Analysis, 11(1), 21-40. https://doi.org/10.1108/eb028961

Muhsin. (2005). Pengaruh Komunikasi Interen dan Kepemimpinan Kepala Sekolah Terhadap Efektivitas Kerja Guru dan Karyawan SMP Negeri 1 Suruh Kabupaten Semarang. Jurnal Universitas Negeri Semarang. p: 122-141

Mula, D. M. (2013). Examining emotional intelligence and transformational leadership within US Army National Guard leaders (Doctoral dissertation, Walden http://search.proquest.com/openview/0ac881299aa7335687dafc67e70927c1/1?pqorigsite $=$ gscholar \&cbl $=18750 \&$ diss $=\mathrm{y}$

Nasution, P. H. (2013). PERANAN KOMUNIKASI ORGANISASI TERHADAP EFEKTIVITAS KERJA PERSONIL DI KEPOLISIAN RESOR KABUPATEN ROKAN HULU(Doctoral dissertation, Universitas Islam Negeri Sultan Syarif Kasim Riau). http://repository.uin-suska.ac.id/id/eprint/7843

Putra, I. P. Y. P., Perdana, P. Y., Adnyani, I., \& Dewi, G. A. (2013). Pengaruh Gaya Kepemimpinan Transformasional, Komunikasi dan Disiplin Kerja Terhadap Kinerja Karyawan Koreseri dan Body Repair pada PT Merpati Bali. Didapat dari: download. portalgaruda. org/article. php.

Reza, M. A., Firdaus, M., \& Novianti, T. (2015). Analysis of Food Price Stabilization in Indonesia (Doctoral dissertation, thesis, Bogor Agricultural University, Bogor). https://fem.ipb.ac.id/miicema/e-journal2/wpcontent/uploads/2015/09/ajemav2n12art4.pdf

Rosita, E. (2016). Analisis naratif pemberitaan majalah tempo terkait kasus Setya Novanto (Doctoral dissertation, Universitas Multimedia Nusantara). http://kc.umn.ac.id/id/eprint/264

San Lam, C., \& Eleanor, O. (2013). Emotional intelligence and leadership styles in China. Asia Pacific Management Review. http://www.airitilibrary.com/Publication/PublicationIndex/10293132

Schlechter, A. F., \& Strauss, J. J. (2008). Leader emotional intelligence, transformational leadership, trust and team commitment: Testing a model within a team context. SA Journal of Industrial psychology, 34(1), $42-53$. http://www.scielo.org.za/pdf/sajip/v34n1/05.pdf

Simamora, F. N. (2018). Pengaruh komunikasi dan kemampuan sumber daya manusia terhadap efektivitas kerja pegawai kantor camat sibolga sambas kota sibolga. Warta Dharmawangsa, (55). http://jurnal.dharmawangsa.ac.id/index.php/juwarta/article/viewFile/216/211

Surbakti. (2013). Analisis Pengaruh Kepemimpinan Transformasional dan Motivasi terhadap Kinerja Pegawai: Studi pada PT. Kereta Api Indonesia Daop IV Semarang . Journal Fakultas Ekonomi Universitas Diponegoro Semarang. 1 (1), p.55-67.

Tabassi, A. A., Ramli, M., \& Dashti, K. F. (2013). Transformational Leadership and Team Effectiveness in Construction Industry. Strategic Leadership Review, 3(4), 69. https://slr.scholasticahq.com/article/69.pdf

Tantriana, T., \& Aris, M. A. (2016). Tax Avoidance: Faktor-Faktor Yang Mempengaruhinya (Studi Empiris Perusahaan Nonperbankan Go Public yang Masuk penilaian CGPI Tahun 2009-2014) (Doctoral dissertation, Universitas Muhammadiyah Surakarta). http://eprints.ums.ac.id/id/eprint/43253

Vierimaa, J. (2013). Emotional Intelligence and Project Leadership. Unpublished MA Thesis. Göteborg, Sweden: Chalmers University of Technology. http://publications.lib.chalmers.se/records/fulltext/183270/183270.pdf

Wahba, M., Leary, R., Ochoa-Lleras, N., Safi, J., \& Brennan, S. (2016, October). A ROS-Simulink Real-Time Communication Bridge Using UDP With a Driver-in-the-Loop Application. In ASME 2016 Dynamic Systems and Control Conference (pp. V002T23A002-V002T23A002). American Society of Mechanical Engineers. https://proceedings.asmedigitalcollection.asme.org/proceeding. aspx ?articleid=2604480

Yukl, G. (2008). How leaders influence organizational effectiveness. The leadership quarterly, 19(6), $708-722$. https://doi.org/10.1016/j.leaqua.2008.09.008

Suwandana, I. G. M. (2019). Role of transformational leadership mediation: effect of emotional and communication intelligence towards teamwork effectiveness. International Research Journal of Management, IT and Social Sciences, 6(2), 52-62. https://doi.org/10.21744/irjmis.v6n2.608 


\section{Biography of Author}

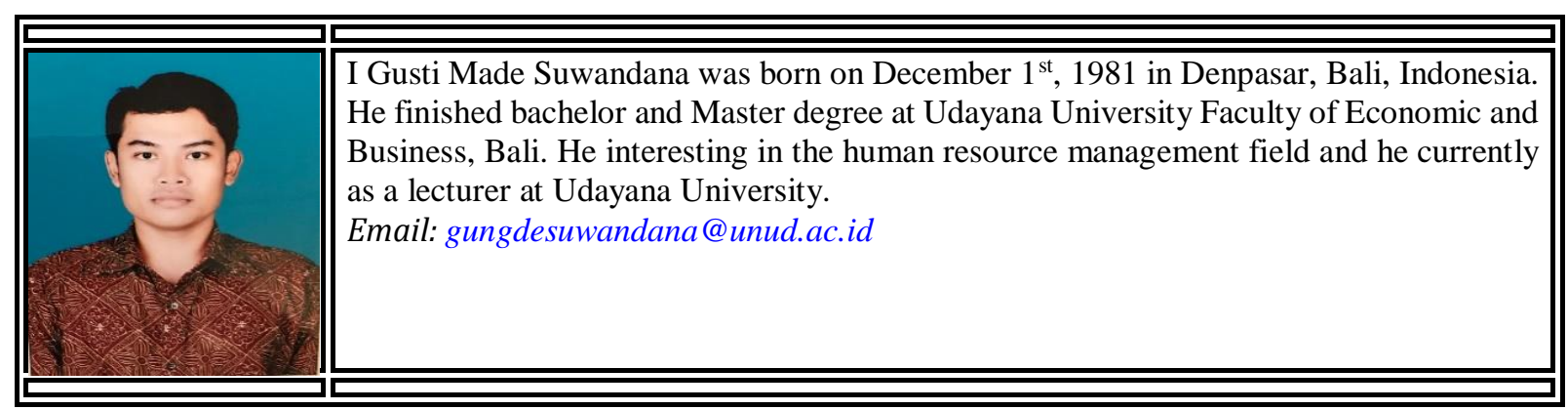

